\title{
Unia Europejska - rozpad czy powrót do równowagi makroekonomicznej i finansowej? Rozważania na temat kryzysu w strefie euro z perspektywy europejskiej i światowej
}

W analizie udostępnionej pod koniec 2011 roku ekonomiści banku ING pod kierownictwem Marka Cliffe'a (Chief Economist of the ING Group) wyliczyli, że w pierwszym roku po rozpadzie strefy euro jej PKB spadłby o niemal 9 proc. Rozpad strefy euro groziłby więc katastrofą gospodarczą w Europie. Eksperci ING uwzględnili przy tym dwa scenariusze dalszego rozwoju sytuacji na starym kontynencie. W pierwszym ze strefy euro wychodzi lub jest do tego zmuszona Grecja. W drugim rozpada się cała strefa euro. W ostatnim z przypadków spadek PKB państw obecnej strefy euro $\mathrm{w}$ ciągu dwóch lat sięgnąłby 12 proc., czyli znacznie więcej niż ubytek w PKB po bankructwie amerykańskiego banku inwestycyjnego Lehman Brothers we wrześniu 2008 roku. Ekonomiści z ING szacuja, że nawet w 2016 roku poziom PKB państw strefy euro byłby o 10 proc. niższy, w porównaniu ze scenariuszem zakładającym przetrwanie strefy. Zdaniem ING kompletny rozpad strefy euro spowodowałby katastrofę nie tylko w gospodarce europejskiej, ale i światowej. W pierwszym roku po rozpadzie strefy i powrocie do narodowych walut gospodarka członków strefy euro skurczyłaby się o 8,9 proc., w kolejnym roku o dalsze 2,2 proc. Największy spadek PKB w 2012 roku odnotowany zostałby w Grecji (o 13,1 proc.), Portugalii (o 12,7 proc.) i we Włoszech (o 10,1 proc.). Gospodarka Niemiec w ciagu roku po rozpadzie skurczyłaby się o 7,4 proc., a gospodarka amerykańska o 0,2 proc. Bezrobocie w strefie euro wzrosłoby o 3 pkt proc. do poziomu 13,2 proc., a w Hiszpanii sięgnęłoby nawet 25,9 proc. Wiele państw - szczególnie z południowej Europy - musiałoby się zmierzyć z dużym osłabieniem walut narodowych, co spowodowałoby drastyczny wzrost inflacji w takich krajach jak: Grecja, Portugalia czy Hiszpania. „Nowa grecka drachma mogłaby się osłabić o... 80 proc.” - piszą w raporcie 
analitycy banku. Z drugiej strony mogłoby nastapić umocnienie np. niemieckiej marki, co z kolei u naszych zachodnich sąsiadów wywołałoby deflację. Rozpad strefy euro spowodowałby drastyczny wzrost kosztów zaciągania kredytów, co znacząco ograniczyłoby aktywność inwestycyjną przedsiębiorstw. Kryzys wywołany rozpadem strefy spowodowałby też zapaść na rynku nieruchomości. Ceny domów w Grecji spadłyby o ponad 35 proc. w ciagu trzech lat, a w Portugalii o niemal 25 proc. Ceny akcji spółek giełdowych spadłyby o kilkadziesiąt procent w ciagu roku po rozpadzie strefy. Z wizji ING wynika, że także Polska poważnie odczułaby rozpad euro area. Gdyby strefa euro - hipotetycznie - rozpadła się w 2011 roku, w kolejnym roku spadek PKB Polski sięgnąłby 6,6 proc. a bezrobocie w 2012 roku sięgnęłoby 16,8 proc. W Polsce mielibyśmy więc największy kryzys gospodarczy od czasów transformacji systemowej z 1989 roku.

Mniej drastyczny scenariusz rozpatrywany przez ekonomistów ING przewidywał scenariusz pierwszy, czyli hipotetyczne wyjście Grecji ze strefy euro pod koniec 2011 roku. Miałoby to zdecydowanie mniejsze negatywne konsekwencje dla pozostałych państw strefy. W pierwszym roku po powrocie Grecji do drachmy, strefa euro wpadłaby w „lekką” recesję - jej PKB skurczyłby się w 2012 roku o 1,6 proc. Recesja w Grecji sięgnęłaby 10,7 proc., a gospodarka Niemiec skurczyłaby się o 0,2 proc.

Bank ING w swych ocenach nie jest przy tym osamotniony. Z przeprowadzonej w listopadzie 2011 roku ankiety Reutersa wynika, że 14 na 20 cenionych ekonomistów sądzi, że strefa euro nie przetrwa w swej obecnej postaci. W negatywnych prognozach wobec dalszych losów strefy euro przodują Brytyjczycy. Według brytyjskich analityków z The Centre for Economics and Business Research małe szanse na przetrwanie strefy euro w obecnym kształcie spowodowane są zbyt dużymi nierównościami pomiędzy gospodarkami strefy ${ }^{1}$.

1 STREFA EURO, Straszne życie bez euro. Upadek waluty wywoła potężna recesje, „Gazeta Wyborcza”, 2.12.2011, http//www.wyborcza.biz. Zob. również: Koniec euro na wiosnę? Wg Brytyjczyków szanse sq spore, http//www.wyborcza.biz, Reuters, aktualizacja: 31.12.2010. Szerzej na temat przyczyn i przebiegu kryzysu finansowego w USA i jego konsekwencjach w innych regionach świata zob. w: W. Szymański, Kryzys globalny. Pierwsze przyblizenie, Warszawa 2009; Zagadki wzrostu gospodarczego. Sity napędowe i kryzysy - analiza porównawcza, red. nauk. L. Balcerowicz, A. Rzońca, Warszawa 2010; J. B. Taylor, Zrozumieć kryzys finansowy. Przyczyny, skutki, interpretacje, Warszawa 2010; Globalny kryzys a jednoczaca się Europa, red. nauk. W. Siwiński, D. Wojtowicz, Warszawa 2010. 
Wykres 1. Makroekonomiczne skutki rozpadu strefy euro w projekcji banku ING

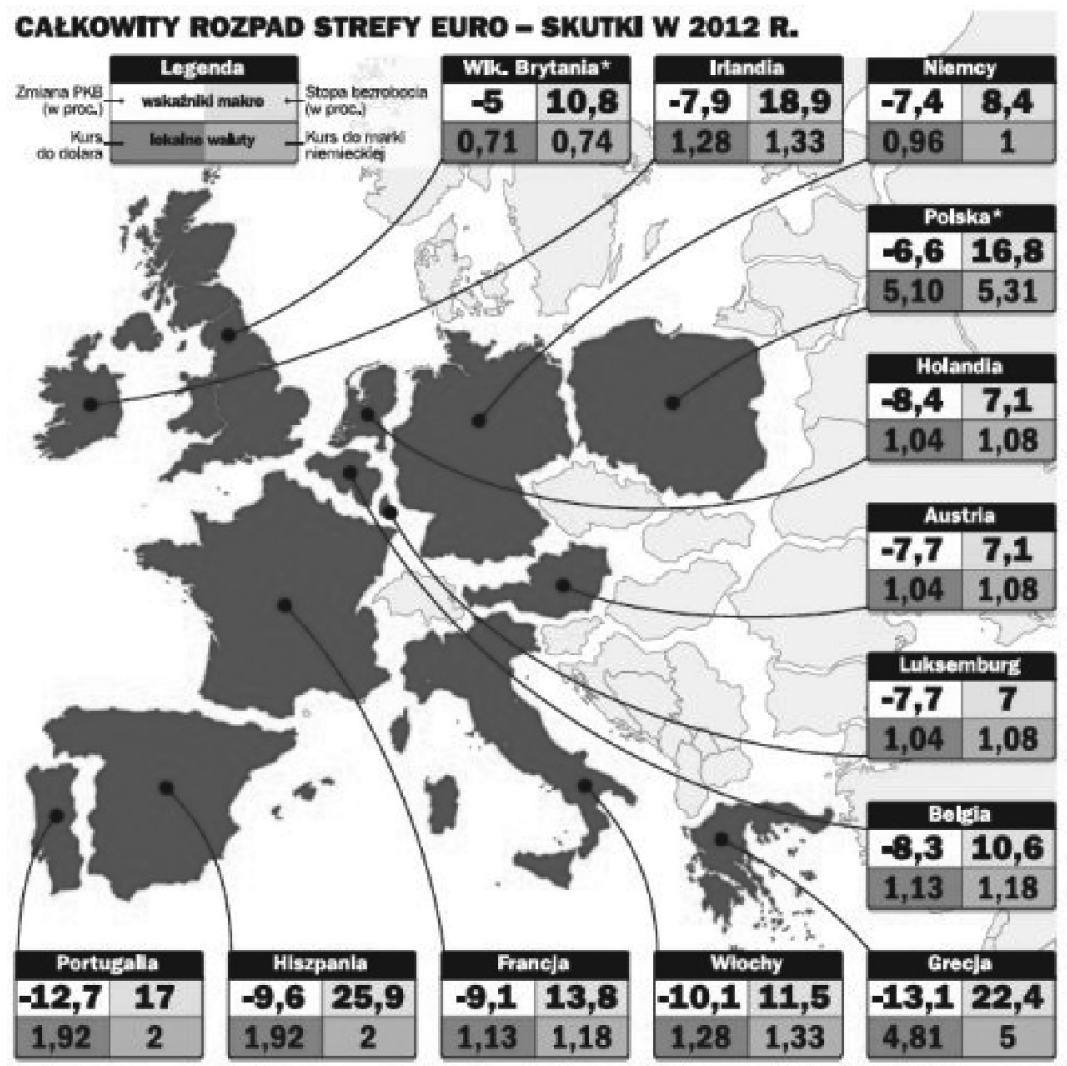

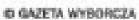

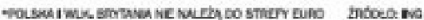

Źródło: ING.

Raport szwajcarskiego banku UBS z września 2011 roku zatytułowany Rozpad strefy euro - konsekwencje podaje z kolei, że ewentualne wyjście Grecji, Portugalii i Irlandii ze strefy kosztowałoby ich podatników kwotę od 9,5-11,5 tys. euro per capita, czyli około 40-50 proc. ich PKB. Opuszczenie strefy musiałoby się wiązać z powrotem do walut narodowych i ich niemal natychmiastową dewaluacją średnio o około 60 proc. Tym samym bardzo wzrosłyby koszty obsługi zadłużenia dla firm i obywateli (obciążenia budżetowe $\mathrm{z}$ tym związane, drastycznie rosnące raty kredytów hipotecznych i obrotowych zaciagniętych w euro i podobnie dotkliwe straty w wartościach depozytów liczonych w euro). Poważne 
problemy przeżywałyby banki (wycofywanie oszczędności oraz niechęć do zaciaggania kredytów i pożyczek) i inne instytucje finansowe. Odczuwalnie wzrosłyby też wskaźniki inflacji. Koszty życia drastycznie zwiększyłyby się, choć z drugiej strony zdeprecjonowane waluty narodowe podniosłyby konkurencyjność międzynarodową krajowego eksportu (np. w branży turystycznej). Musiałyby temu jednak towarzyszyć głębokie reformy strukturalne, bo jak widać na „nieco egzotycznych” przykładach Białorusi czy Zimbabwe sama dewaluacja waluty narodowej gospodarki na pewno nie uzdrawia. Dodatkowo dodać należałoby koszty przygotowania, wyprodukowania i wprowadzenia do obrotu nowych monet i banknotów. W sytuacji gdyby Niemcy zdecydowały się na opuszczenie strefy aprecjacja marki względem euro (zakładając - chyba nieco nazbyt optymistycznie - że strefa euro w jakimś składzie bez Niemiec by przetrwała) spowodowałaby odczuwalne podrożenie eksportu, spadek obrotów handlowych i koszty rzędu 20 proc. PKB. Ogółem koszt wystapienia dużego, rozwiniętego państwa ze strefy euro UBS szacuje na $3,5-4,5$ tys. euro per capita ${ }^{2}$.

${ }^{2}$ R. Omachel, Ile kosztuje rozpad eurolandu?, „Newsweek”, 17-23.10.2011. W dyskusję o konieczności ratowania strefy euro w celu zapobieżenia globalnemu kryzysowi finansowemu zaangażowali się także pozostali ,,gracze globalni" (global players) - USA, Chiny i Brazylia. I tak podczas obrad unijnych ministrów finansów we wrześniu 2011 roku we Wrocławiu, do szukania rozsądnej równowagi między cięciami wydatków a pobudzaniem wzrostu gospodarczego namawiał Europejczyków amerykański sekretarz skarbu Timothy Leithner. Widmo zapaści strefy euro skłoniło brazylijskiego ministra finansów Guido Mantegę do obietnicy, że kraje grupy BRICS (Brazylia, Rosja, Indie, Chiny i RPA) spotkają się, aby ustalić, jak mogą pomóc Europie. Dalsze inwestycje w Europie zapowiedziały też Chiny, które od dwóch lat są drugą gospodarką świata, a globalny kryzys znacząco nie zahamował ich wzrostu. Chiny dysponują dziś największymi rezerwami walutowymi świata. W 2010 r. ich nadwyżka w handlu z USA wyniosła 273 mld USD. Chiny, zwane „bankierem Ameryki” ze względu na masowy zakup amerykańskich obligacji, posiadają 3,2 bln USD rezerw dewizowych, których część bez problemu mogłyby przeznaczyć na zakup obligacji państw grupy PIIGS. Unia Europejska jest przy tym najważniejszym partnerem handlowym Chin. W 2010 r. obroty handlowe Chin i UE wyniosły 479 mld USD. Raport europejskiego European Council for Foreign Affairs szacuje chińskie inwestycje w Europie na 64 mld USD. Chiny wstępnie obiecały pomóc zadłużonej Europie, ale postawiły też trudny do spełnienia warunek. UE powinna bowiem uznać, że Chiny stanowią już gospodarką w pełni rynkową (umowa WTO zakłada taką możliwość dopiero w 2016 roku). Praktyczne znaczenie tego zastrzeżenia jest takie, że status wolnego rynku chronić będzie Chiny przed skargami antydumpingowymi, a w ostatniej dekadzie Unia wielokrotnie oskarżała Chiny o to, 
Jeden z najczęściej cytowanych dziś ekonomistów w świecie Nouriel Roubini przestrzega przed postępującą dezintegracją w Europie, grożącą kontynentowi w sytuacji gdyby strefa euro nie znalazła odpowiedniego panaceum na przeciwdziałanie kryzysowi w grupie PIIGS. „Znalezienie kompromisu w UE wydaje się misją niemożliwą do spełnienia. Dlatego martwię się, że koniec końców zamiast większej politycznej, gospodarczej i fiskalnej integracji, która powinna następować, mamy do czynienia z dezintegracją, która ostatecznie doprowadzi do rozpadu strefy euro. Zagrożenia, z którymi musimy się zmierzyć, są niezwykle poważne. Systemowym zagrożeniem dla globalnej gospodarki są teraz peryferyjne regiony UE, które mogą zarazić kolejne państwa. Trudno jest przecenić to zagrożenie" - podkreślał Roubini podczas Europejskiego Forum Nowych Idei odbywającego się we wrześniu 2011 roku w Sopocie. Zdaniem Roubiniego, w UE powinny zostać opracowane mechanizmy wyjścia ze strefy euro dla „krajów, które nie powinny były do niej zostać przyjęte" jak Grecja, albo notorycznie łamiące zasady dyscypliny finansowej. Przyznał, że obecnie nie ma podstaw prawnych wykluczenia Grecji ze strefy euro, ale nakreślił możliwy scenariusz, który może ją zmusić do odejścia. Amerykański ekonomista nakreślił bardzo pesymistyczny obraz Unii Europejskiej, która nie radzi sobie z zapobieżeniem rozpadu strefy euro. „W UE jest deficyt demokracji, a ludzie mają poczucie, że są rządzeni przez biurokratów z Brukseli. Trzeba iść w kierunku większej unii politycznej ze wzmocnioną rolą Parlamentu Europejskiego, tak by poprawić legitymizację władzy w UE. To może być też sposób na przeciwdziałanie zniechęceniu obywateli wobec większej integracji w UE" - zauważył. Przyznał jednak, że do takiej unii potrzeba politycznego przywództwa, którego brak, bowiem obecni liderzy europejscy nie dorównują proeuropejską charyzmą Helmutowi Kohlowi czy Francois Mitterandowi ${ }^{3}$.

Potencjalny rozpad strefy euro stał się więc przedmiotem ożywionej debaty naukowej, nie wspominając już o politycznej. Jan Zielonka, profesor Studiów Europejskich na Uniwersytecie w Oksfordzie, pytany o to czy obecny kryzys strefy euro może unicestwić Unię Europejską stwier-

że łamią zasady wolnego handlu i zalewają rynek europejski sztucznie tanimi towarami. Zob. T. Bielecki, M. Kruczkowska, Kryzys w strefie euro. Boja się Chiny, USA i BRICS, Bruksela, http//www. wyborcza.biz, aktualizacja: 15.09.2011.

${ }^{3}$ Roubini: strefa euro może się rozpaść, a to grozi światowym kryzysem, http//www.biznes.gazetaprawna.pl/, PAP, aktualizacja: 29.09.2011. 
dził: „...Może. Nie wiemy, co się tak naprawdę wydarzy, takiej sytuacji nie było jeszcze w historii Unii. Żeby przewidzieć, czy integracja europejska upadnie, trzeba być astrologiem, a ja jestem akademikiem. Jakie mamy alternatywy dla Unii? Powrót do systemu westfalskiego, w którym wszystkie państwa były formalnie równe i suwerenne i zamiast współpracować, zaciekle walczyły o granice i wpływy? Ten system był źródłem wielu wojen, w tym dwóch potwornych wojen światowych. [...] Musimy zadać sobie pytanie, co się stanie, kiedy UE przestanie być ośrodkiem stabilizującym sytuację, a państwa członkowskie nie będą się zjeżdżały do Brukseli, by dyskutować o swoich interesach narodowych. Dawniej Amerykanie sprzątali nasze europejskie podwórko. Dziś nie możemy na to liczyć. Kto miałby więc wypełnić tę próżnię władzy po Unii? Najwięksi aktorzy w Europie, w tym Niemcy. Ale Niemcom nie uśmiecha się pozycja przywódcy i dlatego cały czas oglądają się na Unię. [...] Są trzy powody, dla których należy poważnie obawiać się dezintegracji europejskiej. Po pierwsze, państwa europejskie tak bardzo się od siebie uzależniły, że w wypadku ewentualnego upadku strefy euro możemy oczekiwać czegoś, co nazwałbym «zwijaniem się» integracji. Zgodnie z teorią funkcjonalizmu, w którą wierzył jeden z ojców integracji Jean Monet, integracja $\mathrm{w}$ jednej dziedzinie pociągała zacieśnienie współpracy i integrację $\mathrm{w}$ innych dziedzinach $\mathrm{z}$ uwagi na rosnącą współzależność między krajami. Wspólnota Węgla i Stali miała taki wpływ na gospodarkę, że siłą rzeczy integracja się «rozlewała» na inne dziedziny życia, np. na rynek. Jeśli dziś przy takiej dużej współzależności gospodarek europejskich zawali się euro, to zawali się wspólny rynek i Schengen. [...] Druga niepokojąca sprawa to niezdolność obecnych przywódców do równoczesnego rozwiązania problemów w różnych dziedzinach życia. Dziś cała dyskusja w Unii koncentruje się na sprawach finansowych i monetarnych - jak uratować euro, jak poradzić sobie z deficytem itd. Nie ma dyskusji na temat makroekonomicznych skutków popularnej dziś w Europie polityki oszczędności i dyscypliny. A są eksperci, którzy mówią, iż taka polityka hamuje rozwój gospodarczy, bo w obrocie jest mniej pieniędzy. Nikt też nie rozmawia na temat społecznych skutków polityki zaciskania pasa. Weźmy np. Włochy i Grecję. Problemy tych krajów wzięły się z czegoś, co można nazwać «kulturą politycznego feudalizmu». Elity polityczne manipulowały kapitałem i władzą poza oficjalną sceną polityczną. Czy pakiet ratunkowy zaordynowany Grecji przez UE zmieni tę kulturę? Odpowiedź brzmi: nie. Jeżeli dziś sprywatyzuje się tanio wielki sektor państwowy w Gre- 
cji, to kto na tym położy rękę? Ta sama elita polityczna, przez którą Grecja ma kłopoty, bo tylko oni mają pieniądze. A kto we Włoszech ma pieniądze? Silvio Berlusconi. W Unii brakuje pomysłu na to, jak kompleksowo załatwić różne problemy na różnych płaszczyznach. To prowadzi do trzeciego punktu. Dziś nie wiadomo, kto jest suwerenem, np. w Grecji? Rynki finansowe? Unia Europejska? Rząd w Atenach? Każda z tych sił troszczy się o swoje. Rynkom zależy tylko na zdrowych finansach i równowadze budżetowej. Unii - głównie na sprawach instytucjonalnych, żeby stworzyć dobrze funkcjonujący system podejmowania decyzji. A rządom państw członkowskich zależy na utrzymaniu legitymacji politycznej, czyli na rozwiązywaniu problemów społecznych, bo wiedzą, że zaciskanie pasa może prowadzić do rewolucji. Niestety, wszystkie te siły podważają się nawzajem. Na przykład rynki nie przejmują się sprawami instytucjonalnymi, a UE nie daje Grecji możliwości odwołania się do elektoratu w sprawie reform w referendum"4.

W lipcu 2011 roku ministrowie finansów strefy euro, czyli Eurogrupa, po wielu miesiącach braku decyzji, swoistej kakafonii opinii i poglądów musieli wreszcie przyznać, że kryzys finansowy nie dotyczy już wyłącznie małej gospodarki Grecji, ale rozlał się także na trzecią i czwartą gospodarkę europejska, czyli Włochy i Hiszpanię ${ }^{5}$.

Kryzys „2008+” ujawnił, że wizja „Europy dwóch prędkości” po potencjalnym rozpadzie strefy euro $\mathrm{w}$ jej dotychczasowej formule może się ziścić, i to nie w ramach dotychczas postrzeganego podziału na tzw. starą Unię (UE-15) i tzw. nową Unię (UE-10 i UE-2), ale w samym centrum procesów integracyjnych, jego rdzeniu - strefie euro. W przeciwieństwie bowiem do pogrążonych w głębokim kryzysie gospodarczym i finansowym gospodarek państw grupy PIIGS, Niemcy, Francja, Holandia, Szwecja czy Finlandia w latach 2010-2011 odnotowały przyzwoite wyniki gospodarcze, mając dobrą (Niemcy, Beneluks, gospodarki państw nordyckich) lub względnie dobrą (Francja, Austria) sytuację makroekonomiczną ${ }^{6}$.

4 Razem z euro zawali się wspólny rynek i Schengen. Z J. Zielonką rozmawia Jacek Pawlicki, http//www.info.wyborcza.pl/temat/wyborcza/zielonce, aktualizacja: 5.12.2011. Szerzej zob. w: J. Zielonka, Europa jako Imperium. Nowe spojrzenie na Unię Europejska, Warszawa 2007.

5 Huge mess, untidy solutions, (Finance and economics), „The Economist”, July $16^{\text {th }} 2011$.

6 Europe's diverging economies. Nothern lights, southern cross, „The Economist", May $21^{\text {st }} 2011$. 
Bieżący kryzys ekonomiczny w Europie wzmógł też dyskusję o relacjach na linii „polityka-rynek”, w kontekście krytyki neoliberalnego kierunku rozwoju świata. W maju 2010 roku kanclerz. A. Merkel w związku z tym stwierdziła: „Musimy na nowo stworzyć prymat polityki nad rynkiem”. W słowach tych dopatrywać można było sugestii wzmocnienia nadzoru i kontroli instytucji unijnych, jak i państwowych nad działalnością finansowych i niefinansowych korporacji, a także innych działań interwencjonistycznych na rynku. Z drugiej strony także inwestorzy światowi z rozmaitych funduszy inwestycyjnych równie często wysyłali sygnały o niskiej stabilności gospodarczej poszczególnych państw europejskich, poważnych błędach gospodarczych ekip rządzących, przez lata prowadzących nierozsądną politykę rozwojową bezrefleksyjnie zadłużając swe społeczeństwa. Polecali oni rządom państw UE następującą formułę ,jeżeli nie chcesz denerwować się opiniami inwestorów, nie pożyczaj dużo pieniędzy od nich"7.

Strefa euro niewątpliwie posiada potencjał służący przeciwdziałaniu bieżącemu kryzysowi. Jej zagregowany deficyt budżetowy i dług publiczny - o czym rzadko się wspomina - prezentuje się lepiej niż te same wskaźniki traktowane łącznie w Stanach Zjednoczonych i W. Brytanii. Problemem jest jednak słaba decyzyjność, nieumiejętność właściwego nadzoru i kontroli gospodarczej, egzekwowania przyjętych zobowiązań oraz brak politycznej jedności interesów w strefie.

Problem z Grecją polega też na tym, że według badań ankietowych 60 proc. Greków jest przeciwnych rygorystycznym warunkom, na jakich ,trojka” (UE-EBC-MFW) udzielała lub nadal udziela im pomocy finansowej w ramach EFSF (ang. EFSF). Jednocześnie 70 proc. społeczeństwa, będąc świadomym wielu negatywnych wręcz katastrofalnych konsekwencji nie chce, aby ich kraj dobrowolnie lub pod przymusem opuszczał strefę euro ${ }^{8}$.

Bezrobocie w Grecji nadal utrzymuje się na bardzo wysokim 21 proc. poziomie, a według przewidywań recesja będzie greckim problemem przez kolejne kilka lat. W roku 2011 gospodarka według prognoz KE skurczyć miała się o 5,5 proc, a w 2012 o kolejne 2,5 proc., przy jednoczesnych wysokich deficytach budżetowych. W ciagu ostatnich pięciu lat grecka gospodarka skurczyła się aż o 14 proc., a niezadowolenie społeczne wyrażające się w masowych protestach publicznych (szczegól-

${ }^{7}$ Buttonwood? Firefighting, ,The Economist”, July $16^{\text {th }} 2011$.

8 Greece and the euro. Papandndreou's people, ,The Economist”, November $5^{\text {th }} 2011$. 
nie w Atenach i Salonikach) nadal jest duże ${ }^{9}$. Grecki plan prywatyzacyjny budzący tak wiele kontrowersji społecznych i politycznych do roku 2015 ma przynieść 50 mld euro - ekwiwalent 20 proc. PKB. Nie byłby to przy tym ewenement. W latach 1985-1998 dziewięć państw europejskich, w tym Portugalia sprzedała majątek państwowy na zbliżoną kwotę. Grecja jednak - co stanowi ryzyko - chce to uczynić w nieporównywalnie krótszym czasie. $Z$ jednej strony może to budzić wątpliwości, co do należytej wyceny majątku, z drugiej jednak wydaje się być wyjściem bezalternatywnym. Rentowność greckich obligacji sukcesywnie rosła (oznaczało to spadek zaufania inwestorów), a indeksy giełdowe podobnie jak ratingi wiarygodności kredytowej malały. Dodatkowo narastało niezadowolenie społeczne wśród społeczeństw innych państw UE, których podatnicy w ramach mechanizmu wsparcia finansowego EFSF zobligowani zostali do udzielenia pomocy Grecji. Najlepiej oddawał to przykład Niemiec. Poczytny niemiecki tabloid „Bild” przy dużej, bo ponad 60 proc. aprobacie społecznej apelował na swych łamach „Sprzedajcie swoje wyspy! Grecy - jesteście bankrutami! i Akropol też!"10.

Problem losów Grecji nadal jest więc aktualny, bo jak stwierdził J. M. Barosso koszty wyjścia Grecji ze strefy euro byłyby dla UE wyższe niż koszty jej dalszego wspierania. Grecja do lutego 2012 nadal nie porozumiała się z prywatnymi instytucjami finansowymi w sprawie redukcji zadłużenia, sięgającego 347,2 mld euro, czyli 159,1 proc. PKB. Grecy nadal bez pomocy „trojki” nie są w stanie sami spłacać swych zobowiązań, pomimo wykorzystania już 73 mld euro. Wielu ekonomistów wprost wskazuje na poziom zadłużenia rzędu 60-70 proc PKB, kiedy to Grecja byłaby w stanie sama obsługiwać swój dług. Wymagać to będzie wielkiej determinacji i konsekwencji we wdrażaniu radykalnych rządowych planów oszczędnościowych oraz skuteczności w ściaganiu rosnących podatków. Problem tkwi jednak w tym, że Grecję co kilka miesięcy paraliżują organizowane przez wielkie centrale związkowe strajki generalne, a sytuacja polityczna i stabilność „,rządu ocalenia narodowego" L. Papademosa wydawały się chwiejne ${ }^{11}$.

9 Greece's woes. Debts, downturns and demonstrations, „The Economist”, October $8^{\text {th }} 2011$.

10 The euro's problems. Tomorrow and tomorrow, „The Economist”, May $21^{\text {st }}$ 2011; Greece's debt crisis. Bail-out 2.0, „The Economist”, June $11^{\text {th }} 2011$.

11 Szerzej zob. w: Greckie nieszczęścia, przedruk z „The Economist”, „Rzeczpospolita”, 16 stycznia 2012; L. Baj, T. Prusek, Grecja walczaca, „Gazeta Wyborcza”, 
Wykres 2. Poziom deficytu budżetowego w Grecji w latach 2010-2012 (jako proc. PKB oraz w relacji do roku poprzedniego)

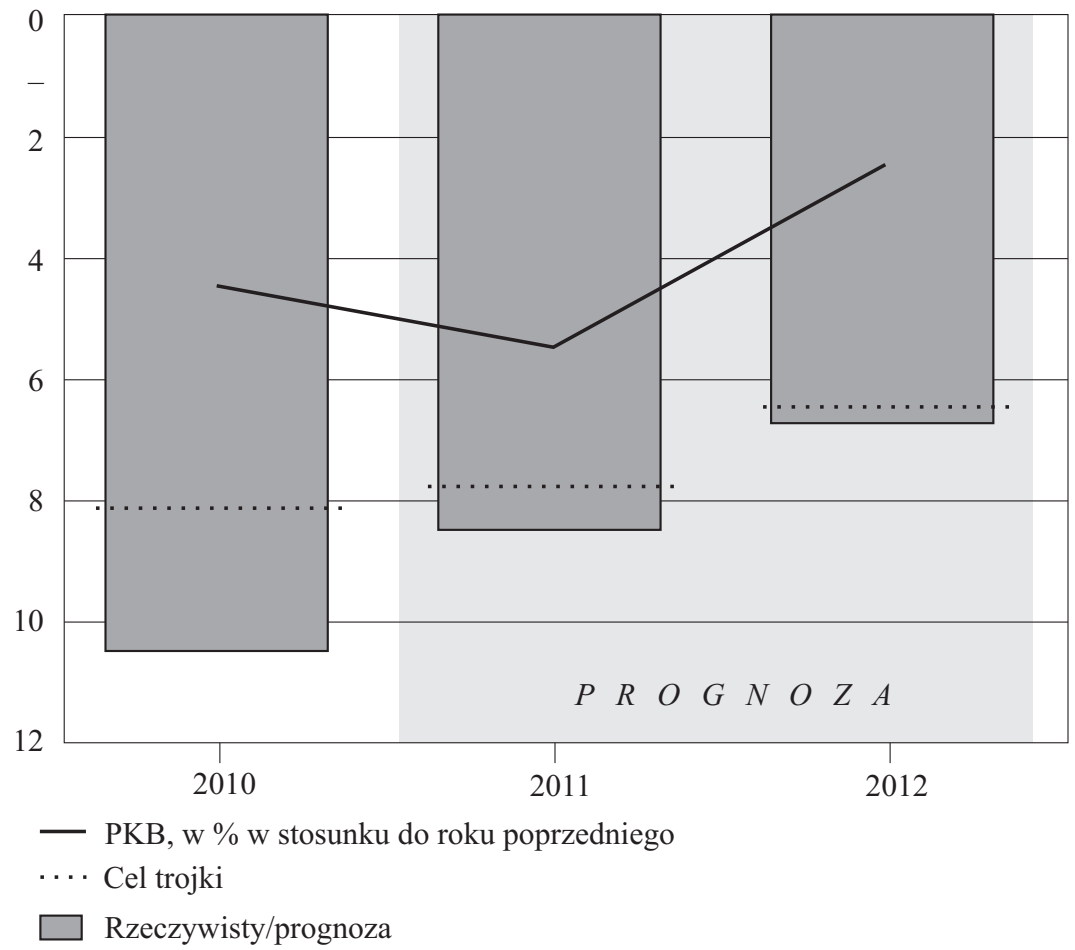

Źródło: Greckie ministerstwo finansów.

Część inwestorów, już w lipcu 2011 roku uznało, że następną po Grecji ofiarą kryzysu w strefie euro mogą się stać Włochy. Analogię pomiędzy Włochami a Grecją znaleźć nietrudno. Obydwie gospodarki są poważnie zadłużone (dług publiczny większy od rocznego PKB), obydwie mają niezrównoważone budżety, wreszcie obydwie potrzebują pilnych reform strukturalnych w celu zapobieżenia bankructwu. Zauważalne są jednak także istotne różnice. Przede wszystkim Włosi w odróżnieniu do pozostałych państw grupy PIIGS są niepomiernie mniej uzależnieni od wierzycieli zagranicznych. W 2010 roku ich międzynarodowe zobowiązania finansowe netto wyniosły zaledwie 24 proc. PKB, czyli

8 lutego 2012; T. Bielecki, L. Baj, M. Piotrowski, Grecja na rozdrożu, „Gazeta Wyborcza", 14 lutego 2012. 
Wykres 3. Poziom oprocentowania dziesięcioletnich obligacji greckich na tle włoskich i niemieckich - czerwiec-wrzesień 2011 (dane w proc., im wyższe oprocentowanie, tym gorzej dla danego kraju, bo oznacza wyższy koszt obsługi zadłużenia)

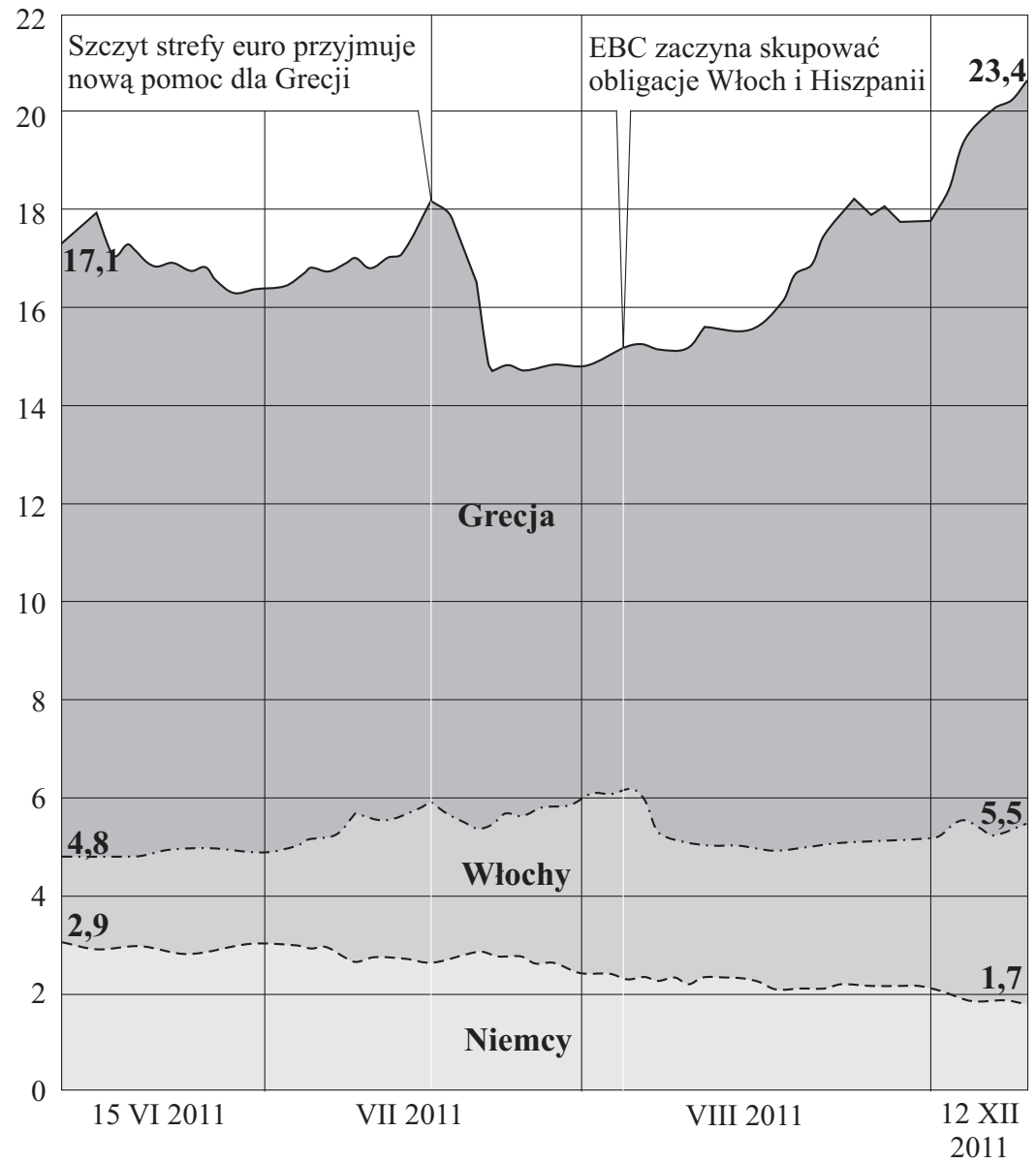

Oprocentowanie polskich obligacji 10-letnich denominowanych w złotych sięga 5,7 proc.

Źródło: Dane Bloomberg.com zawarte w: „Gazeta Wyborcza”, 13.09.2011.

porównywalnie z W. Brytanią i USA, ale nieporównywalnie mniej od Grecji (96 proc.), Portugali (107 proc.) i Hiszpanii (90 proc.). Ponadto Włochy posiadają wiele światowej klasy branż i globalnych korporacji, o wielkim i nadal nie do końca wykorzystanym potencjale. Podobna kwestia dotyczy włoskiego sektora MSP, który pod warunkiem stworze- 
nia mu lepszego otoczenia biznesowego i prawnego ma szanse zacznie dynamiczniej się rozwijać ${ }^{12}$.

Eksperci zgodnie podkreślają, że przypadek włoski jest więc inny od greckiego, a także irlandzkiego czy portugalskiego. „Grecji do wypłacalności potrzebne są oszczędności rzędu 20 proc. PKB. We Włoszech wystarczy wysiłek konsolidacyjny rzędu 4 proc. PKB. W dodatku dług włoski aż w 50 proc. jest w posiadaniu inwestorów krajowych, co zmniejsza podatność na panikę anonimowych inwestorów, którzy często nie wiedza, co się dzieje w gospodarce danego kraju" - stwierdził Paolo Manasse, profesor ekonomii na Uniwersytecie Bolońskim. W jego opinii Włochy, w odróżnieniu od Grecji, Portugalii i Irlandii razem wziętych, niezmiernie trudno byłoby uratować wspólnym wysiłkiem UE, EBC i MFW. Obecny fundusz ratunkowy strefy euro wynosi jak wiadomo 440 mld euro. Według szacunków wielu ekonomistów na wypadek kryzysu we Włoszech i Hiszpanii należałoby go zwiększyć do minimum $1-1,5$ bln euro ${ }^{13}$.

Włochy mają co prawda duży problem ze swym ponad 120 proc. długiem publicznym, ale też duży potencjał eksportowy, który mógłby być znacznie wzmocniony, gdyby udało się rządowi skutecznie poprawić konkurencyjność całej gospodarki. Wyjściu Włoch z kryzysu długo nie pomagały przy tym spory polityczne, szczególnie na linii premier Berlusconi-minister finansów Tremonti. Pierwszy niemal powszechnie krytykowany był za beztroski stosunek do sfery finansów publicznych, drugi posiadał duże zaufanie wśród inwestorów w świecie. Kłótnie w byłym już rządzie włoskim najlepiej obrazuje przykład: S. Berlusconi, znany z dosadnego i kwiecistego języka w jednym z wywiadów stwierdził, że G. Tremonti to: „ktoś kto myśli że jest geniuszem, wierząc że wszyscy inni to kretyni"14.

Problemem rządu S. Berlusconiego była niechęć do jakichkolwiek głębszych, liberalnych reform strukturalnych. Przeciwnie na fali narodowego patriotyzmu w 2008 roku Berlusconi sprzeciwił się przejęciu bankrutujących linii Alitalia przez AirFrance. Generalnie pomimo podkreślania swego rzekomo rynkowego podejścia do życia i pracy były włoski pre-

12 Italy's economy. That sinking feeling, „The Economist”, November $12^{\text {th }} 2011$.

13 A. Słojewska, Nagonka rynków na Włochy, http//www.rp.pl, ostatnia aktualizacja: 12.07.2011.

14 The eurozone on the edge. The Road to Rome, (Finance and economics), ,The Economist", July $16^{\text {th }} 2011$. 
mier prowadził swój gabinet bez jasnej i spójnej wizji ekonomicznej, przez lata sztucznie podtrzymując propagandowo (głównie za sprawą swych licznych kanałów TV) optymizm społeczny. Ostateczna kompromitacja S. Berlusconiego, także za sprawą głośnej afery obyczajowej zwanej ,,bunga-bunga” wymogła zmianę rządu na bardziej technokratyczny, wzorowany na rozwiązaniu z 1995 roku, gdy władze (także po Berlusconim) przejął Lamberto Dini. Prezydent Napolitano misję tworzenia „rządu ocalenia narodowego" ostatecznie powierzył cenionemu ekonomiście i byłemu komisarzowi unijnemu Mario Montiemu ${ }^{15}$.

Premier Włoch na początku grudnia 2011 roku przedstawił parlamentowi plan 30 mld euro oszczędności budżetowych do 2014 roku, przyjęty następnie przez parlament. Pakiet przedstawiony przez rząd Mario Montiego składa się z sumy 12-13 mld cięć w wydatkach na administrację publiczną (m.in. likwidacja „rządów” w 110 włoskich prowincjach i liczebne ograniczenie ich rad samorządowych) oraz z 17-18 mld euro nowych podatków (np. podatek od pierwszej nieruchomości, bowiem dotychczas płaciło się tylko za drugi i kolejny dom bądź mieszkanie oraz podatek od luksusu, czyli od posiadanych prywatnych samolotów, jachtów mających więcej niż 10 metrów czy najdroższych modeli samochodów). Rząd Mario Montiego, zamierzał też nałożyć podatek solidarnościowy na „najwyższe emerytury”, choć nie określił jego progu. Włoski rząd zarezerwował sobie prawo do podwyżki podatku VAT, ,jeśli będzie to konieczne”, o 2 pkt proc. (od września 2012 r.), czyli stawki podstawowej z 21 do 23 proc. (wcześniej podniesiono ją z 20 do 21 proc.). Rząd oszczędności budżetowe wprowadził w formie dekretu. Najbardziej bolesna część reform dotyczy emerytur - świadczenia wyższe od 960 euro miesięcznie nie będą waloryzowane o stopę inflacji w latach 2012-2013. Rząd zamierza przyspieszyć podnoszenie wieku emerytalnego dla mężczyzn (obecnie 65 lat) i kobiet (60-61 lat w zależności od miejsca pracy). Wiek emerytalny dla Włoszek i Włochów

15 Addio, Silvio, (Briefing, The Italian crisis), „The Economist”, November $12^{\text {th }}$ 2011; T. Bielecki, Parlament Włoch zatwierdzit wczoraj pakiet oszczędnościowy wart 30 mld euro. Włoskie zaciskanie pasa. Pakiet oszczędnościowy zatwierdzony, Bruksela, http//www.rp.pl, aktualizacja: 22.12.2011. Sposobem, w jaki premier Mario Monti przedstawił szczegóły dekretu zyskał sympatię i zrozumienie rodaków. Najpierw ogłosił on, że w obliczu poważnej groźby bankructwa państwa rezygnuje z pensji premiera i ministra gospodarki, co nie zdarzyło się jeszcze nigdy w historii republiki włoskiej. Odwołując się do patriotyzmu rodaków, dekret oszczędnościowy zatytułował „Ratujmy Włochy” (Salva Italia). 
wzrośnie do 66 lat już w 2018 r. i do 67 lat w 2022 r. (pierwotnie planowano to dopiero na 2026 r.).

Zadowolenia z przedstawionych oszczędności nie kryli przedstawiciele Komisji Europejskiej. Ich zdaniem reformy Montiego to „krok w dobrym kierunku". Włoski rząd obiecuje zrównoważenie swego budżetu do 2013 r., pomimo przewidywanej recesji 0,4-0,5 proc. PKB w 2012 r. Około 20 mld euro oszczędności z nowego pakietu ma pójść na zmniejszenie długu publicznego, a pozostała część na pobudzanie wzrostu gospodarczego, m.in. poprzez ulgi podatkowe za tworzenie nowych miejsc pracy dla ludzi młodych. Mario Monti zaniechał jednocześnie części trudnych, choć zapowiadanych wcześniej reform, m.in. otwarcia (deregulacji) zamkniętych zawodów (w tym aptekarza i taksówkarza). Co ciekawe, były minister finansów Giulio Tremonti, co prawda w izbie niższej parlamentu głosował za „pakietem Montiego”, ale równocześnie skrytykował nowego premiera za ,zbytni nacisk na dodatkowe podatki, zbyt mało cięć w wydatkach oraz brak silnych bodźców na rzecz wzrostu" (prognozowana recesja we Włoszech to $0,4-0,5$ proc. w 2012 r.). Plan Salva Italia z zadowoleniem przyjęli też światowi inwestorzy giełdowi. Nazajutrz po jego ogłoszeniu główne indeksy na giełdzie w Mediolanie zwyżkowały o 2-3 proc. Drastycznie też spadło rynkowe oprocentowanie włoskich obligacji 10-letnich. Po raz pierwszy od ponad miesiąca było ono niższe niż 6 proc. $^{16}$

16 L. Baj, Monti przekonat rynek? Przedstawit plan 30 mld euro oszczędności, http//www. pieniadze.gazeta.pl, aktualizacja: 6.12.2011. W 2012 roku włoski rząd musi wykupić zapadające papiery skarbowe warte ponad $300 \mathrm{mld}$ euro, z czego ponad połowa od stycznia do kwietnia 2012 roku (choć nie oznacza to, że musi wyemitować aż tyle obligacji, bo część może wykupić, płacąc np. posiadaną już gotówką). Kluczowe znaczenie ma oprocentowanie emitowanych papierów. Im drożej włoski rząd pożycza, tym więcej będzie musiał płacić za obsługę zadłużenia. Dlatego po ogłoszeniu planu ratowania Włoch „Salva Italia” wszyscy z niecierpliwością czekali na aukcję bonów skarbowych. Wyszła ona nadzwyczaj dobrze. Włochy sprzedały sześciomiesięczne bony warte 9 mld euro przy średnim oprocentowaniu na poziomie 3,25 proc. (miesiąc wcześniej sięgało ono aż 6,5 proc.!) Inwestorzy wykupili też dwuletnie obligacje za 1,7 mld euro (oprocentowanie spadło z 7,8 do 4,85 proc). Zob. L. Baj, Włoski test na wiarygodność. Po bonach czas na obligacje, http//www.pieniadze.gazeta.pl, aktualizacja 28.11.2011; Italy's budget. Saving Italy, "The Economist", December $10^{\text {th }} 2011$ oraz Briefing: The Italian crisis. Europe's debt crisis. Rushing for the exits, ,The Economist”, November $12^{\text {th }} 2011$. 
Wykres 4. Wartość zapadających obligacji i bonów skarbowych Włoch, Francji i Hiszpanii w 2012 roku (dane w mld euro, na koniec listopada 2011 r.)

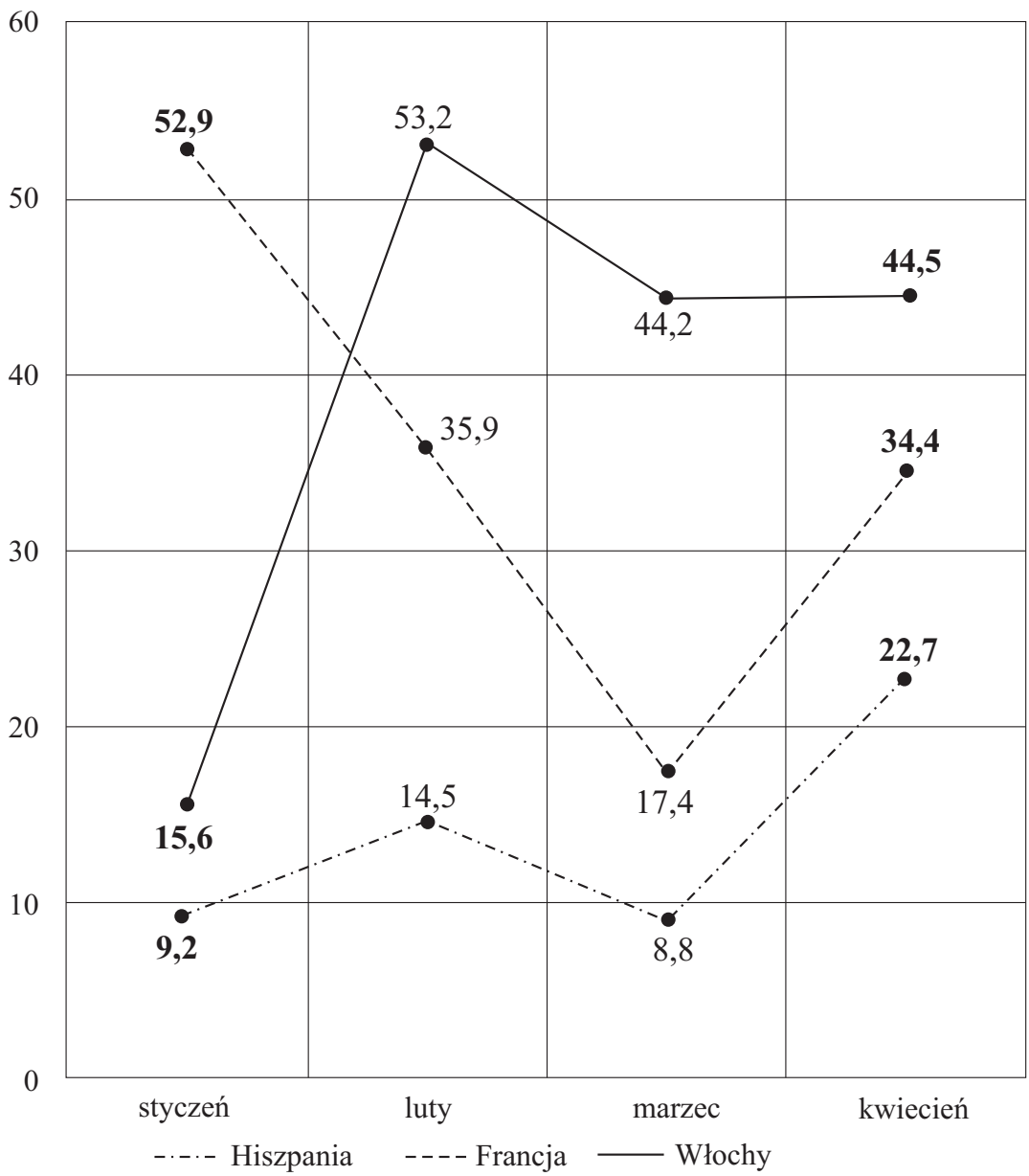

Źródło: „Der Spiegel”, Bloomberg, http//www.wyborcza.biz.

Odrębnym tematem pozostają problemy gospodarki hiszpańskiej. Sytuacja ekonomiczno-społeczna w Hiszpanii przez ostatnie lata w dużym skrócie wyglądała następująco: „młodzi ludzie chcą pracy, światowe rynki reform a obywatele nowego rządu". Rząd Jose Luisa Zapatero przez dwa lata zaprzeczał, że sytuacja finansowa kraju jest zła. Dopiero recesja gospodarcza i galopujące bezrobocie zmusiło jego gabinet do ogłoszenia spóźnionego programu bardzo niepopularnych zresztą 
społecznie reform, których głównym celem jest zredukowanie narastającego deficytu budżetowego z poziomu 11,1 procent w 2009 roku do 4,4 procent na koniec 2011 roku. Jednym z jego elementów jest też wydłużenie (z małymi wyjątkami) czasu pracy do 67 roku życia. Największymi krytykami rządu socjalistów byli studenci i w ogóle rzesze młodych Hiszpanów pozostających od lat bez stałego zatrudnienia lub w ogóle bez pracy. Na bardzo wysokie wskaźniki bezrobocia w Hiszpanii duży wpływ (analogia do Irlandii) miało pęknięcie bańki spekulacyjnej na rynku nieruchomości. W przemyśle budowlanym w czasie największej prosperity zatrudnionych było aż 13 procent Hiszpanów! Do dziś straszą w tym kraju szkielety setek tysięcy rozpoczętych i niedokończonych budów. Nieoficjalne szacunki mówią nawet o niemal 4 milionach niezasiedlonych mieszkań i setkach bankrutujących developerów. Wydaje się, że tylko nowa ekipa rządząca i zdecydowanie bardziej restrykcyjny program oszczędnościowy mógł stworzyć tej iberyjskiej gospodarce szanse na powrót na prawidłową ścieżkę rozwoju. Plan minister gospodarki i finansów Eleny Salgado Mendez zakładał wzrost PKB w 2011 roku zaledwie o 0,6 proc. oraz 1,1 proc. w 2012 roku i problemu wysokiego, strukturalnego bezrobocia na pewno w Hiszpanii nie rozwiąże $e^{17}$.

W 2011 roku deficyt budżetowy w Hiszpanii najprawdopodobniej przekroczy zakładane wcześniej 6 proc. PKB. Nowy rząd M. Rajoya powtarza, że jego celem na 2012 rok jest deficyt w wysokości 4,4 proc. PKB. Aby znaleźć brakujące 30 mld euro, nowy hiszpański premier będzie musiał zdecydować się na cięcia wydatków budżetowych i zapewne odczuwalne podwyżki podatków. Zdaniem niektórych analityków M. Rajoy zmuszony zostanie do podniesienia podatku VAT, który obecnie jest jednym z najniższych w strefie euro. Pewnym problemem Hiszpanii jest też udział złych kredytów w całym portfelu hiszpańskich banków, które udzieliły łącznie 145,17 mld USD złych kredytów. Stanowią one 5,81 proc. wszystkich udzielonych pożyczek. W listopadzie 2011 roku wskaźnik ten wyniósł 5,68 proc., a w październiku $-5,66$ proc. $\mathrm{Z}$ tego powodu rząd może być zmuszony do ubiegania się o pożyczkę z EFSF, szcze-

17 Spanish politics. The unhappy campers, „The Economist”, May $28^{\text {th }} 2011$; Spains economic outlook. Reforming Zapatero, ,The Economist”, February $5^{\text {th }} 2011$; Spain and the euro crisis. A great burden for Zapatero to bear (Europe), „The Economist", January $22^{\text {nd }} 2011$. 
gólnie że opinie inwestorów na temat kondycji gospodarki iberyjskiej są nawet gorsze niż jej stan faktyczny. Z drugiej strony trudno się temu dziwić, biorąc pod uwagę choćby fakt, że w połowie 2012 roku po raz pierwszy w historii Międzynarodowy Czerwony Krzyż ogłosił apel o pomoc dla Hiszpanii, w której wg MCK 22 proc. ludności żyje poniżej progu ubóstwa, a na wyciągnięcie ich $\mathrm{z}$ nędzy potrzeba minimum 30 mld euro. O słabnącym zaufaniu do objętej recesją gospodarki świadczy też to, że jedynie w kwietniu 2012 roku z Hiszpanii firmy i osoby prywatne przeniosły do innych banków, w mniej zagrożonych kryzysem krajach, aż 66 mld euro. Hiszpania oficjalnie wciąż zaprzecza jednak, aby pomocy „trojki” potrzebowała, mimo że środków w budżecie (choćby 23 mld euro na ratowanie banku Bankia) ewidentnie brakuje ${ }^{18}$.

Dalsze losy Unii Europejskiej w kontekście skutecznej walki z kryzysem gospodarczym i finansowym uzależnione są jednak nie tylko od efektów reform w Grecji, we Włoszech czy Hiszpanii, ale także od kondycji największych gospodarek europejskich i największych donatorów wsparcia finansowego w ramach EFSF, czyli Niemiec i Francji. Pewnym optymizmem napawa więc fakt, że niemiecki urząd statystyczny Destatis w styczniu 2012 roku podkreślił w swym raporcie, że gospodarka Niemiec w 2011 r. była w bardzo dobrej kondycji. PKB Niemiec powiększył się w minionym roku o 3 proc. w porównaniu z 3,7 proc. rok wcześniej. Motorem rozwoju był głównie popyt wewnętrzny, w szczególności wydatki konsumpcyjne. Wzrosły one w 2011 roku o 1,5 proc. - najwięcej od pięciu lat. Jednocześnie 0,8 pkt proc. do stopy wzrostu

18 Rząd Hiszpanii chce podnieść podatki, by zmniejszyć deficyt, http//www.wyborcza.biz, Reuters, aktualizacja: 19.12.2011; Hiszpania ma najwięcej złych kredytów od 15 lat, http//www.wyborcza.biz, AFP, aktualizacja: 18.02.2011. Tysiące Europejczyków w poszukiwaniu pracy opuszcza swoje kraje i wyjeżdża do Argentyny (byłej kolonii hiszpańskiej) czy nawet... Angoli (byłej kolonii portugalskiej). Na ulicach Buenos Aires coraz częściej słychać język angielski i włoski, a szczególnie język hiszpański. „Co roku do Argentyny emigruje 1200 młodych Hiszpanów” - alarmował podczas kampanii wyborczej nowy już premier Mariano Rajoy. Jako przyczynę podawał kryzys gospodarczy, w jakim od kilku lat pogrążony jest jego kraj. Portugalczycy (dziesiątki tysięcy rocznie!) wyjeżdżają z kolei do swych byłych kolonii: Brazylii, Angoli i Mozambiku. Nie są to tylko pracownicy fizyczni jak w przeszłości, a też młodzi, dobrze wykształceni ludzie z grupy tzw. „białych kołnierzyków" np. inżynierowie i architekci. Zob. Argentyna ziemiq obiecanq dla Hiszpanów $i$ Włochów, http//www.gazeta.pl, aktualizacja: 23.12.2011 oraz A. Wądołowska, Bezrobotni Portugalczycy szturmuja dawne kolonie, http//www.gazeta.pl, aktualizacja: 1.09.2011. 
gospodarczego wniósł handel zagraniczny. Eksport powiększył się 8,2 proc., a import o 7,2 proc. I właśnie duże znaczenie, jakie ma dla Niemiec eksport, budzi wśród ekonomistów największy niepokój. Z Niemiec - największej gospodarki europejskiej napływają więc nieco sprzeczne sygnały. Co prawda we wrześniu 2011 r. eksport wzrósł o 0,9 proc, ale już produkcja w stosunku do roku poprzedniego spadła o 2,7 proc. (nowe zamówienia ogółem nawet o 4,3 proc., a te ze strefy euro aż o 12,1 proc.). Bez watpienia spowolni to eksport produktów, z których słynie ten kraj (np. samochodów, drogich towarów konsumpcyjnych trwałego użytku, nowoczesnych maszyn i urządzeń przemysłowych), wnoszący niemal 50 proc. w niemieckie PKB, którego wzrost w 2012 roku szacuje się - według różnych prognoz - na 0,5-0,9 proc. Pozytywnie z kolei nastrajają malejące wskaźniki bezrobocia (prognoza 6,9 proc. w 2012 roku) i stopniowo rosnące dochody ludności (5-3 proc. brutto w latach 2011-2012), które przy kontrolowanej inflacji powodują rosnący popyt wewnętrzny, gwarantując pewien stan zrównoważenia w gospodarce ${ }^{19}$. Sporym problemem gospodarki niemieckiej jest wysoki, zbliżony do francuskiego poziom zadłużenia (83 procent w relacji do PKB). Dlatego też Niemcy na wzór Szwajcarii i Polski (60 proc. próg ostrożnościowy zapisany w konstytucji) zadecydowali o wprowadzeniu rozwiązań na wzór „hamulca zadłużenia”. I tak rząd federalny do roku 2016 zobowiązał się do ograniczenia deficytu strukturalnego do poziomu 0,35 proc. PKB (szesnaście rządów landowych ma na to czas do 2020 roku). Podobne rozwiązania wprowadziła Hiszpania i Austria ${ }^{20}$.

Natomiast Francja z szóstki państw strefy o najlepszym ratingu AAA ma największy wskaźnik długu w relacji do PKB, od 1974 roku problemy ze zrównoważeniem budżetu, a jej banki mają największą ekspozycję na długi państw grupy PIIGS (szczególnie Włoch). OECD prognozuje przy tym wzrost gospodarczy w 2012 roku na poziomie zaledwie 0,3 proc. PKB (korekta z poziomu 2 proc., założenia rządu francuskiego 1 proc. PKB), a część ekonomistów wieści recesję. Trudno jednak i nie-

19 Europe. Germany's economy. A case of sniffes, ,The Economist”, November $12^{\text {th }}$ 2011 oraz G. Siemionczyk, Ekonomia Niemiec hamuje, http//www.rp.pl, ostatnia aktualizacja: 11.01.2012.

20 Germany's debt brake.Tie your hands please, „The Economist”, December $10^{\text {th }}$ 2011. 
Wykres 5. Poziom deficytu budżetowego (governmental structural deficit) i długu publicznego (governmental gross debt) w latach 2008-2012 w Grecji, Hiszpanii, Francji, Niemczech i we Wloszech (w proc. PKB)

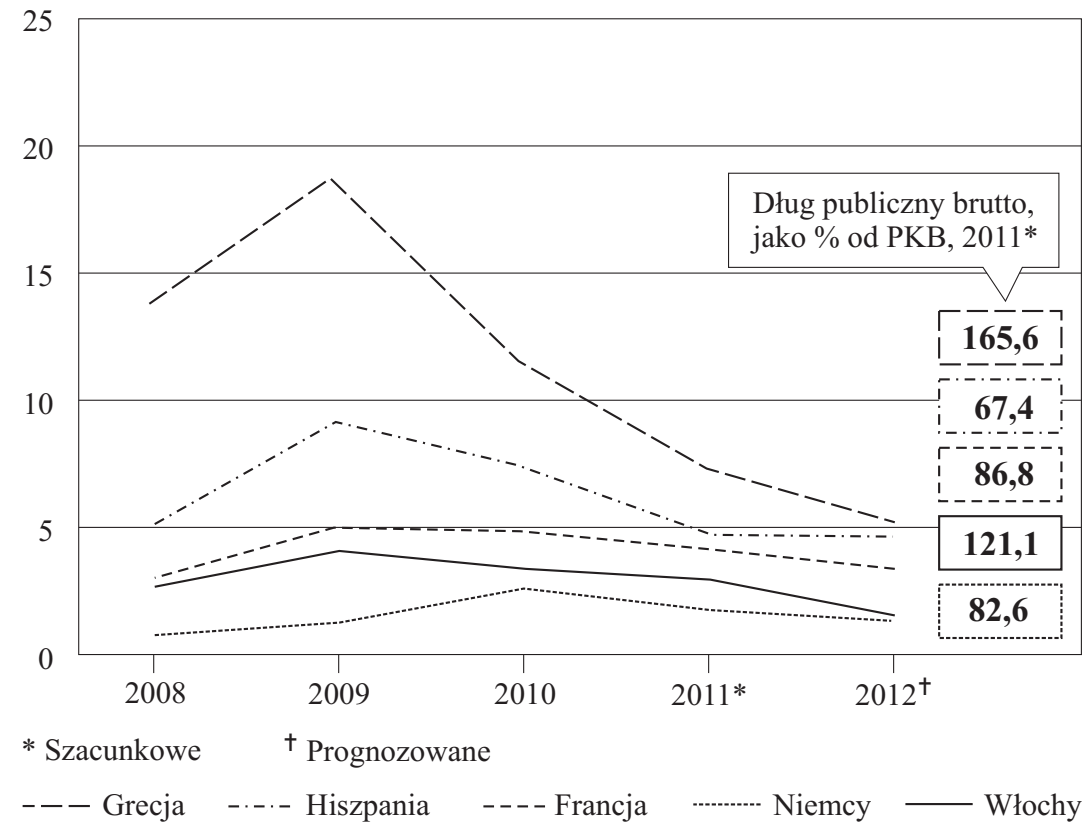

Źródlo: MFW.

uczciwie byłoby porównywać względnie stabilną sytuację makroekonomiczną i finansową Francji z państwami grupy PIIGS ${ }^{21}$.

$\mathrm{Z}$ kolei bardzo dobre ratingi notuje pozostająca poza strefą euro Szwecja. Dotyczy to zresztą także pozostałych państw nordyckich Unii, tj. Danii będącej poza strefą euro i Finlandii będącej jej członkiem (nieco gorsze właśnie z tego powodu oceny wiarygodności kredytowej tego kraju). Przede wszystkim dzięki innowacyjnej, opartej na nowoczesnych usługach i produkcji gospodarce państwom „welfare state” udaje się skutecznie amortyzować skutki obecnego kryzysu, zapewniając przy tym silny, elastyczny i hojny socjalnie rynek pracy (promowana przez Komisję Europejską a wywodząca się z Danii idea flexicurity). W Szwecji szczelna polityka fiskalna zapewnia nadwyżkę budżetową rzędu 0,1 proc. PKB i malejący dług publiczny. Finansową kontrolą i nadzorem,

21 Europe. France and the euro crisis, „The Economist”, December $3^{\text {rd }} 2011$. 
w celu zapobieżenia kryzysowi finansowemu na wzór Islandii, objęta została działalność czterech największych szwedzkich banków (Handelsbanken, Nordea, SEB, Swedbanken). Relatywnie słaba korona zapewnia wysoką konkurencyjność eksportu i wzrost gospodarczy na poziomie 5,7 proc. w 2010 roku (prognoza na 2011 rok wynosiła 4,4 proc.). Jednak spowolnienie w strefie euro w 2012 roku negatywnie odbije się na dynamice szwedzkiego eksportu wnoszącego prawie 50 proc. wkład w PKB, stabilizując wzrost w 2012 roku na poziomie około 1 proc. $\mathrm{PKB}^{22}$.

Wysiłek konsolidacyjny w wydatkach budżetowych widać nie tylko na omawianych przykładach. Przyznać należy, że wychodząc naprzeciw oczekiwaniom Komisji państwa członkowskie Unii Europejskiej, szczególnie z grupy PIIGS coraz wyraźniej i skuteczniej ograniczają wydatki na administrację publiczną, świadczenia socjalne, a nawet (w tym przypadku niestety) na inwestycje. Dodatkowe dochody mają dać im z kolei rosnące podatki i nowe opłaty. Włosi przykładowo nakazali swym obywatelom płacić 10 euro za wizytę lekarską u specjalisty i wystawienie recepty oraz 25 euro za skorzystanie z pomocy pogotowia ratunkowego w niegroźnych dla życia przypadkach. Zniknąć mają w tym kraju prawie wszystkie ulgi podatkowe, a najbogatsi emeryci będą musieli zapłacić dodatkowy podatek w wysokości 5 proc. od świadczenia wynoszącego ponad 90 tys. euro rocznie. Całościowy program naprawczy we Włoszech zakłada oszczędności rzędu 60 mld euro do 2014 roku. Portugalia z kolei - po dwóch latach krytyki, w 2012 roku chwalona wreszcie za program oszczędnościowy - zdecydowała się zamrozić płace w sektorze publicznym oraz zawiesić stosowanie zasady indeksacji emerytur. Poza tym pojawi się tam specjalna składka emerytalna, a wydatki na publiczną służbę zdrowia i szkolnictwo spadną. Jeszcze w 2010 roku uchwalono restrykcyjny plan oszczędności dla Niemiec. Ma on przynieść w ciągu czterech lat około 80 mld euro oszczędności. Od 2011 roku m.in. ograniczono w Niemczech dodatkowe świadczenia dla osób długotrwale bezrobotnych, zlikwidowano ubezpieczenia emerytalne dla pobierających te zasiłki oraz dopłaty do kosztów ogrzewania. Z kolei zasiłki rodzicielskie, wypłacane rodzicom, korzystającym z 12-miesięcznego urlopu wychowawczego, zostały zmniejszone lub zniesione. Pomimo protestów, także w Wielkiej Brytanii, realizowane są poważne cięcia bu-

22 Sweden and the euro. Out and happy, ,The Economist”, December $3^{\text {rd }} 2011$. 
dżetowe i oszczędności w administracji publicznej. Również Węgrzy przyjęli program reform, zakładający m.in. obniżenie wydatków budżetowych o 2,2 mld euro i zwiększenie wpływów o 1,1 mld euro. Zmniejszą się zasiłki dla bezrobotnych, inwalidów oraz dopłaty do lekarstw i komunikacji miejskiej. Do węgierskiego budżetu wpłynie około 10 mld euro z tytułu budzącej wiele kontrowersji w Unii reformy OFE. Wiele państw zdecydowało się też podnieść podatki. Akcyza na benzynę wzrosła m.in. w Irlandii i Wielkiej Brytanii. Niemcy wprowadzili

Wykres 6. Planowane oszczędności w wybranych państwach Unii Europejskiej w l. 2010-2012 (w mld euro)

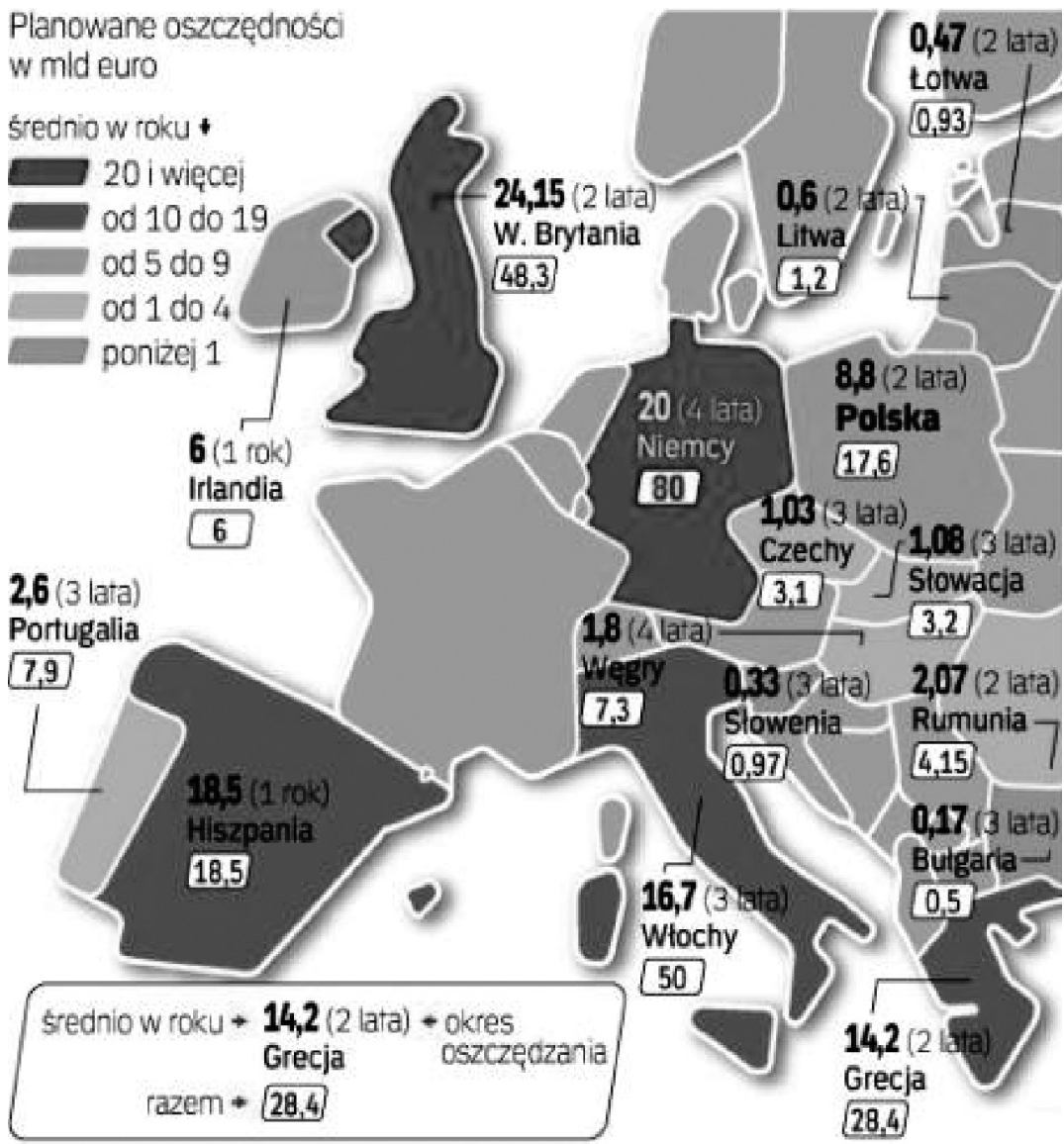

Źródło: Eurostat. 
podatek od komunikacji lotniczej. Podwyżkę VAT zarządziła Wielka Brytania, Polska, Węgry i Czechy ${ }^{23}$.

Pomimo przyjętych na szczeblu Unii Europejskiej i stopniowo realizowanych na poziomie jej państw członkowskich reform gospodarczych, najważniejsze agencje ratingowe (tzw. wielka trójka) w świecie obniżyły lub groziły obniżeniem ocen wiarygodności kredytowej gospodarkom grupy PIIGS. Wyraźnie zirytowało to zarówno ich rządy, jak i Komisję Europejską. I tak, według oceny wiarygodności kredytowej Moody's, jest coraz bardziej prawdopodobne, że Irlandia, na wzór Grecji, będzie potrzebowała drugiego pakietu ratunkowego. Dla Komisji decyzja Moody’s była sporym zaskoczeniem. Zdaniem Olli Rehna, unijnego komisarza ds. walutowych, obniżka irlandzkiego ratingu, i to przed opublikowaniem wyników kwartalnego przeglądu kryteriów gospodarczych, była bardzo dyskusyjna. Jak można się było spodziewać, komunikat agencji spowodował natychmiastową wyprzedaż irlandzkich obligacji. Wycena papierów dwuletnich osiagnęła poziom 18,6 proc. Amerykańska agencja nie ukrywała, że Irlandczycy systematycznie wprowadzaja w życie wszystkie postanowienia, które warunkowały udzielenie jej pomocy w wysokości 85 mld euro. Moody's przyznaje jednak, że ryzyko związane z dalszymi posunięciami konsolidacyjnymi jest zbyt wysokie, przede wszystkim z powodu wyraźnie słabej kondycji irlandzkiej gospodarki. Inne agencje: Standard \& Poor's, KPMG i Fitch, prognoz Moody's z lipca 2011 roku nie potwierdzały ${ }^{24}$.

Podobna sytuacja dotyczyła Portugalii. Komisja Europejska i rząd portugalski nie ukrywały oburzenia obcięciem ratingu Portugalii. Zdaniem przewodniczacego Komisji Jose Manuela Barroso nieuczciwe jest karanie państwa, które skutecznie wprowadza reformy. „Bardzo żałuję decyzji jednej $\mathrm{z}$ agencji ratingowych, która karze kraj zaczynający wprowadzać cięcia. $Z$ całym szacunkiem dla tej agencji, ale nasze instytucje w Portugalii lepiej orientują się w realiach" - stwierdził Barroso, w przeszłości premier Portugalii. W dniu 5 lipca 2011 r. w oparciu o oceny wiarygodności kredytowej agencja Moody's obniżyła rating portugalski o 4 stopnie do poziomu Ba2 i zapowiedziała możliwość dalszego obniżenia tej oceny. Głównym powodem utraty zaufania do Portu-

${ }^{23}$ Europa tnie wydatki na potęgę, http//www.rp.pl, ostatnia aktualizacja: 22.07.2011.

24 D. Walewska, Włosi i Irlandczycy muszq ciąć głębiej, http//www.rp.pl, ostatnia aktualizacja: 13.07.2011. 
galii było - zdaniem Moody’s - duże prawdopodobieństwo, że kraj ten tak samo jak Grecja będzie potrzebował kolejnego pakietu pomocowego. Portugalska gospodarka szybko odczuła obniżony rating. Wprawdzie udało się rządowi sprzedać w lipcu 2011 roku obligacje trzymiesięczne o wartości $848 \mathrm{mln}$ euro, ale były one oprocentowane na poziomie 11,7 , a nie na 10,7 , czyli takim zanim Moody's ujawnił nową ocenę. Z kolei niemiecki minister finansów Wolfgang Schauble nie ukrywał, że zamierza złamać monopol amerykańskich agencji ratingowych, wprowadzając większą konkurencję na rynku. „Dosyć już tych samospełniających się proroctw, które tylko komplikują sytuację krajów starających się ratować gospodarkę" - konstatował W. Schauble. Ogółem funkcjonuje 76 agencji ratingowych w świecie, jednak najdłuższą, kilkudziesięcioletnią historią mogą pochwalić się właśnie S\&P, Moody’s i Fitch. Ich rola wzrosła w latach 30 . XX wieku, gdy z ich prognoz zaczął korzystać rząd USA. Aktualnie za ocenę papierów dłużnych płacą agencjom emitenci, co może i powinno budzić zdziwienie i poważny konflikt interesów. Agencje mogą mieć bowiem pokusę zawyżania ratingów w zamian za hojne wynagrodzenia i chęć związania z sobą (a nie konkurencją) klienta. Spektakularnym przykładem tego typu kontrowersji były bardzo wysokie oceny derywatów (obligacji - CDO, ubezpieczeń - CDS) kredytów hipotecznych wysokiego ryzyka inwestycyjnego typu ,subprime”, jakich trzy agencje udzieliły sprzedającym je inwestorom amerykańskich banków Lehman Brothers (AAA), Morgan Stanley, Goldman Sachs i kilku innych. W ostateczności, jak wiadomo, doprowadziło to do głębokiego kryzysu finansowego i gospodarczego w Stanach Zjednoczonych zwanego „2008+”, który w wyniku globalnej współzależności rozwojowej „rozlał się” na cały świat ${ }^{25}$.

Pod koniec 2011 roku agencja Moody’s groziła obcięciem ratingu nie tylko w strefie euro, ale i całej UE. Eskalacja kryzysu zadłużeniowego w strefie euro i kłopoty sektora bankowego stanowią coraz większe zagrożenie dla oceny wiarygodności kredytowej wszystkich krajów członkowskich Unii - ostrzegła agencja Moody's. Co szczególnie zaskakujące, agencja stwierdziła, że coraz bardziej prawdopodobny wydaje się czarny scenariusz, a mianowicie rozpad strefy euro. W styczniu 2012 roku S\&P obniżył rating dziewięciu gospodarkom strefy euro z Francją i Au-

25 D. Walewska, Bruksela oburzona na decyzje Moody's, http//www.rp.pl, ostatnia aktualizacja: 6.07.2011; G. Siemonczyk, Arbitrzy wiarygodności kredytowej, http//www.rp.pl, ostatnia aktualizacja: 20.01.2012. 
strią na czele oraz samemu EFSF z AAA na AA+, postulując o jego większe dofinansowanie. Co ciekawe ocena ta nie spotkała się $\mathrm{z}$ nadmiernie złą reakcją inwestorów. Może to świadczyć o budzących się wśród nich wątpliwościach, co do obiektywizmu i bezstronności amerykańskich analityków z omawianych trzech agencji. Pomysł złamania monopolu „wielkiej amerykańskiej trójki” poprzez stworzenie własnej, europejskiej agencji ratingowej budzić powinien wiele obaw z podobnych powodów. $\mathrm{Z}$ drugiej jednak strony agencje ratingowe powinny podlegać identycznemu nadzorowi jak cały rynek finansowy, posiadając jednolite standardy metodologiczne ocen. Brak tego rozwiązania spowodował, że agencje popełniły wielkie błędy przy ocenie obligacji i ubezpieczeń hipotecznych Lehman Brothers w 2007 roku, który kilka miesięcy później ,z hukiem” zbankrutowat ${ }^{26}$.

Wykres 7. Rating gospodarek europejskich agencji Moody's - 2011 rok

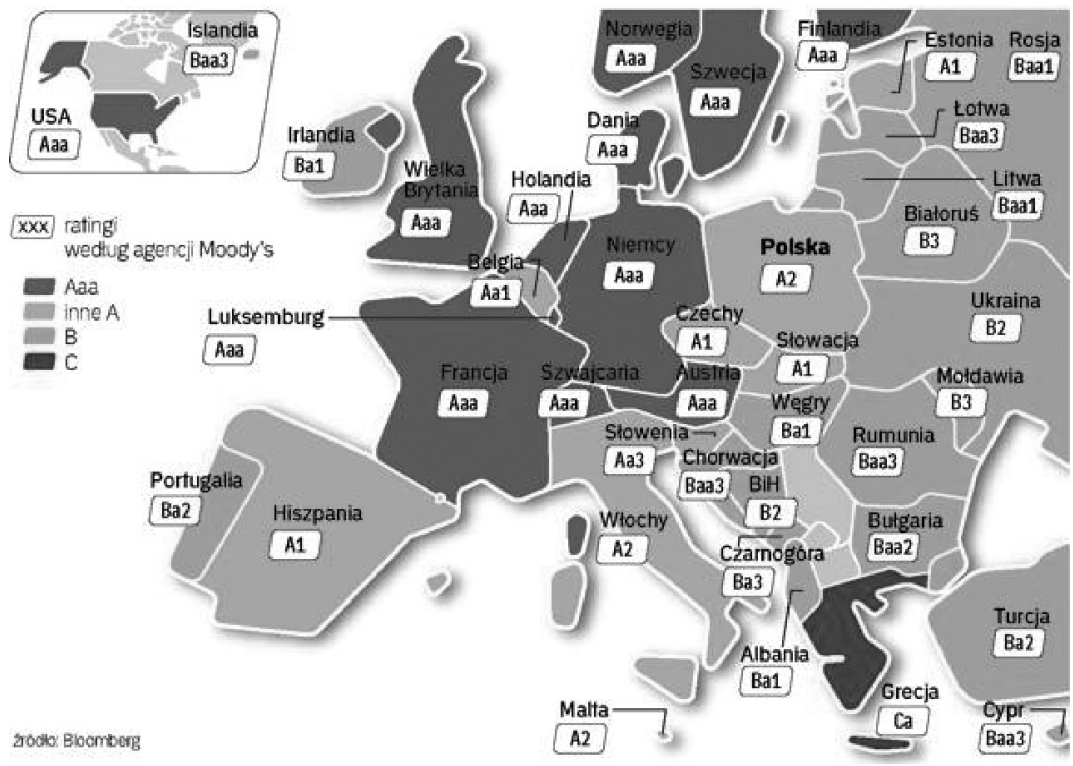

Źródlo: Bloomberg.

26 D. Walewska, Czarny scenariusz agencji ratingowych, http//www.rp.pl, ostatnia aktualizacja 29.11.2011; Panowie życia i ratingu, rozmowa T. Pruska z P. Heweltem, „Gazeta Wyborcza”, 30.01.2012; Banki sa bezpieczne, ale..., rozmowa M. Samcika z L. Niemyckim, „Gazeta Wyborcza”, 27.09.2011. 
Potrójne A (AAA, Aaa) w każdej z agencji ratingowych oznacza najbardziej wiarygodną ocenę kredytową w przypadku długoterminowych zobowiązań dłużnych. Ratingi z grupy podwójnego A (Fitch i S\&P: AA+, AA, AA-; Moody's: Aa1, Aa2, Aa3) oznaczają duże prawdopodobieństwo, że emitent obligacji wywiąże się ze swoich zobowiązań. Pojedyncze A (Fitch i S\&P: A+, A, A-, Moody's: A1, A2, A3) oznaczają, że to prawdopodobieństwo jest mniejsze, chociaż wciąż stosunkowo wysokie. Ostatnią grupą inwestycyjną w miarę pewną dla inwestorów są oceny kredytowe oznaczone potrójnym B (Fitch i S\&P: BBB+, BBB, BBB-, Moody's: Baa1, Baa2, Baa3). Inwestowanie w papiery z ratin-

Wykres 8. Rating gospodarek europejskich agencji S\&P - 2012 rok

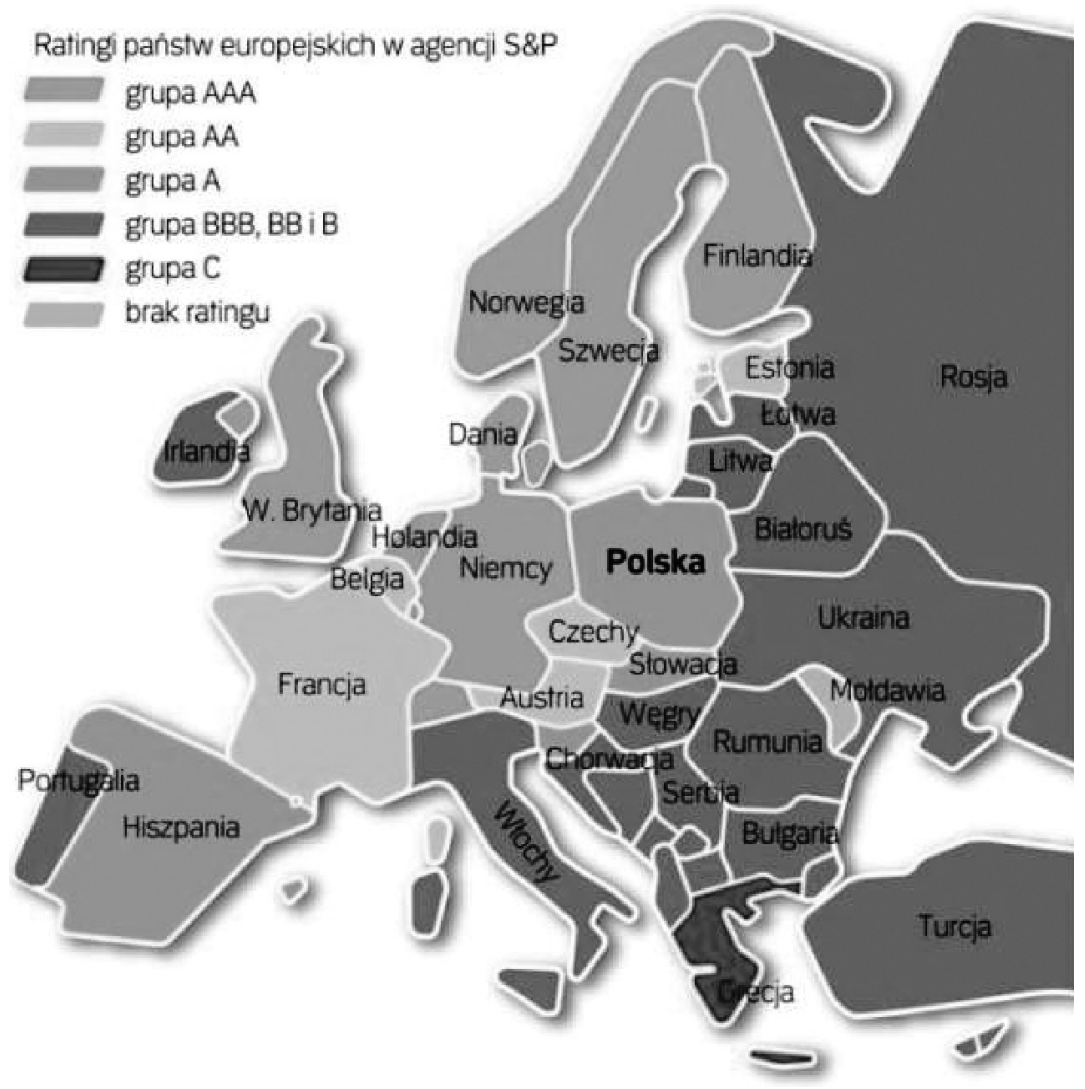

Źródło: Bloomberg. 
giem poniżej tej klasy jest uznawane za ryzykowne. Podwójne oraz pojedyncze B (lub B z pojedynczym ,a”) oznaczają oceny kredytowe nadawane mocno spekulacyjnym papierom. Ratingi z grupy $\mathrm{C}$ wskazują na duże ryzyko bankructwa emitenta obligacji. Grupa D oznacza już bankrutów. Najniższymi ratingami są: D- Fitch i w S\&P oraz C - Moody's (oznaczająca tam bankruta).

W związku z wątpliwościami dotyczącymi wiarygodności ich ocen Komisja Europejska zaproponowała działania służące wzmocnieniu nadzoru nad agencjami ratingowymi. Od momentu wybuchu kryzysu gospodarczego zapoczątkowała reformy w celu poprawy regulacji rynków finansowych i zwiększenia ochrony inwestorów. Jedną ze zmian było wzmocnienie nadzoru nad agencjami ratingowymi, aby uczynić je bardziej odpowiedzialnymi, zapobiec powstawaniu konfliktów interesów, a inwestorom zapewnić więcej informacji. Agencje te związane zostaną nadzorem nowego Europejskiego Urzędu Nadzoru Giełd i Papierów Wartościowych, który będzie mógł stosować wobec nich kary w przypadku naruszenia norm prawnych. Generalnie Komisja apeluje, aby:

- zmniejszyć nadmierne zaufanie do ocen agencji ratingowych;

- wymagać od agencji dokonywania częstszych ocen długów;

- zapewnić ich niezależność;

- zwiększyć odpowiedzialność agencji.

Propozycje Komisji muszą zostać jeszcze zatwierdzone przez poszczególne rządy państw członkowskich UE i Parlament Europejski. Nowe przepisy mają wejść w życie pod koniec 2012 r. $^{27}$

Oprócz problemu wiarygodności agencji ratingowych (obniżenie ratingu kredytowego może skutkować wyższymi odsetkami, czyli oznacza wyższe koszty zaciaganych pożyczek) Komisja słusznie zdiagnozowała najważniejsze wyzwania rozwojowe stojące przed zintegrowaną Europa w najbliższych latach. Zaliczyła do nich wsparcie na rzecz zapewnienia stabilności gospodarce greckiej, poprawę sytuacji europejskich banków (większy nadzór finansowy, ochrona depozytów, rekapitalizacja), powstrzymanie bieżącego kryzysu (zakładana skuteczność EFSF, a od połowy 2012 roku Europejskiego Funduszu Stabilności - EFS), sprawniejszy system zarządzania gospodarczego i finansowego w strefie euro (tzw. sześciopak, potwierdzony propozycją paktu fiskalnego) oraz dzia-

27 Większa odpowiedzialność agencji ratingowych, strona internetowa KE: http// ec.europa.eu/news/economy, 17.11.2011. 
łania na rzecz wzrostu gospodarczego (m.in. Strategia „Europa 2020”, „Akt o jednolitym rynku” czy tzw. „Raport Montiego”) ${ }^{28}$.

Konkludując: potencjalny rozpad strefy euro nie jest w interesie któregokolwiek z państw członkowskich Unii Europejskiej, a nawet innych państw w świecie, z USA i Chinami na czele. Dezintegracja europejska niosłaby za sobą fatalne skutki ekonomiczne, społeczne i finansowe przede wszystkim dla Europy i jej obywateli. Także dla całej zglobalizowanej gospodarki światowej, składającej się z coraz mocniej konkurujących ze sobą, ale i współzależnych rozwojowo gospodarek narodowych nie byłaby informacją dobrą i pożądaną. Unia Europejska w obecnym składzie przetrwa jednak jedynie pod warunkiem wysokiej skuteczności reform wdrażanych w grupie PIIGS. O ile jednak można sobie wyobrazić prawidłowo funkcjonującą strefę euro bez wnoszącej zaledwie 2-3 proc. wkład w jej PKB Grecji (co zasygnalizowała zresztą unijna komisarz Nelly Kroes, a także rządy Niemiec, Holandii czy Finlandii), o tyle byłoby to znacznie trudniejsze bez Włoch i Hiszpanii razem mających ponad 20 proc. udział w zagregowanym PKB strefy. Ich ewentualne bankructwo niosłoby za sobą wielkie niebezpieczeństwo pojawienia się tzw. „,efektu domina” i długotrwałej depresji gospodarczej w całej Europie. „Efekt domina” nie wynikałby przy tym ze znaczenia Grecji w handlu wewnątrzgałęziowym pozostałych państw śródziemnomorskich strefy, lecz z groźby panicznej reakcji światowych inwestorów wycofujących swój kapitał z tego regionu. Demonstracje uliczne, 24-godzinne strajki generalne i inne formy protestów organizowane przez centrale związko-

28 Szerzej zob. w: KOMISJA EUROPEJSKA, Bruksela, 3.03.2010, KOM(2010) 2020 wersja ostateczna, KOMUNIKAT KOMISJ, EUROPA 2020, Strategia na rzecz inteligentnego i zrównoważonego rozwoju sprzyjajacego właczeniu społeczne$m u$; KOMISJA EUROPEJSKA, Bruksela, dnia 13.4.2011, KOM(2011) 206 wersja ostateczna, KOMUNIKAT KOMISJI DO PARLAMENTU EUROPEJSKIEGO, RADY, EUROPEJSKIEGO KOMITETU EKONOMICZNO-SPOŁECZNEGO I KOMITETU REGIONÓW, Akt o jednolitym rynku. Dwanaście dźwigni na rzecz pobudzenia wzrostu gospodarczego $i$ wzmocnienia zaufania , Wspólnie na rzecz nowego wzrostu gospodarczego" $\{\operatorname{SEK}(2011) 467$ wersja ostateczna $\}$; Zarzadzanie gospodarcze w UE: Komisja przedstawia obszerny zestaw środków ustawodawczych, IP/10/1199, Bruksela, 29 września 2010 r. http://ec.europa.eu/economy_finance/articles/eu_economic_situation/2010-09-eu_economic_governance_proposals_en.htm; NOWA STRATEGIA NA RZECZ JEDNOLITEGO RYNKU. ,,W stużbie gospodarki i społeczeństwa Europy. Sprawozdanie dla przewodniczqcego Komisji Europejskiej Jose Manuela Barroso". Przygotował: Mario Monti, 9 maja 2010. 
we w Grecji i Hiszpanii (kwiecień-maj 2012 rok) wskazują jednak, że pewności co do skuteczności wdrażanych reform nadal mieć nie można. W czerwcu 2012 roku dodatkowo okazało się, że poważne problemy finansowe dotknęły Cypr. W kraju tym deficyt budżetowy w 2011 roku wyniósł 6,3 proc., dług publiczny wzrósł do 71,6 proc. a recesja na 2012 rok szacowana jest na 0,8 proc. PKB. „Wielka ratingowa trójka” głównie ze względu na niemożność dokapitalizowania przez rząd podupadających cypryjskich banków obniżyła poziom wiarygodności kredytowej tego kraju do poziomu śmieciowego. Cypryjski prezydent Demetris Christiofas w czerwcu 2012 roku oznajmił w związku z tym, że „nie można wykluczyć” ubiegania się jego kraju o pomoc z EFSF. Podobne deklaracje wielce prawdopodobne, że złoży wkrótce rząd hiszpański.

Ustabilizowaniu sytuacji makroekonomicznej i finansowej służyć może nowy model zarządzania gospodarczego, oparty na większej kontroli, nadzorze budżetowym, ewentualnych karach i ściślejszej koordynacji polityk gospodarczych poszczególnych państw ujęty w tzw. sześciopaku i potwierdzony tzw. paktem fiskalnym (bez udziału W. Brytanii i Czech). Ma on jednak szansę na sukces jedynie przy poprawie systemu podejmowania decyzji politycznych w Unii Europejskiej, czyli wypracowaniu nowego modelu unii politycznej w Europie (apele kanclerz Niemiec A. Merkel). Pozwoliłoby to na skuteczne egzekwowanie postanowień paktu fiskalnego i uniknięcie błędów związanych z łamaniem kryteriów Paktu Stabilności i Wzrostu (Stability and Growth Pact) z Dublina (1997 rok) i brakiem jakichkolwiek sankcji finansowych z tym związanych. Dopiero uporanie się z tymi problemami otworzy w UE przestrzeń do szybkiej i niezbędnej rozwojowo realizacji ambitnych założeń budowy nowoczesnej, opartej na wysokim i stabilnym wzroście gospodarczym oraz wysokich wskaźnikach zatrudnienia gospodarki europejskiej zawartej w strategii „Europa 2020” i innych dokumentach instytucji unijnych. Niewiadomych nadal jest jednak bardzo dużo i co gorsze nie zawsze można je przewidzieć. W Grecji, przynajmniej dla części społeczeństwa, nowym „narodowym bohaterem”, swoistym „męczennikiem za sprawę” stał się 77-letni emerytowany aptekarz, który protestując przeciwko drakońskim cięciom budżetowym w kwietniu 2012 roku zastrzelił się na placu Syntagma w Atenach. Dodatkowo pozostawił on po sobie list otwarty, szeroko nagłośniony następnie w mediach, w którym wzywa grecką młodzież do zbrojnego wystapienia przeciwko rządowi z „kałasznikowami w rękach”. Problem skuteczności 
wdrażanych reform, nie dotyczy zresztą jedynie dalszego rozwoju sytuacji w Grecji (w której wyniki wyborów z maja 2012 roku potwierdziły tylko rosnącą niechęć społeczną do dalszych wyrzeczeń - sukces radykalnie lewicowej koalicji partii SYRIZA), Hiszpanii czy we Włoszech. I tak zwycięstwo w wyborach prezydenckich we Francji (kwiecień/maj 2012) lidera socjalistów Francois Hollande'a niesie za sobą groźbę renegocjacji porozumień francusko-niemieckich uzgodnionych przez N. Sarkozy i A. Merkel w grudniu 2011 roku, które następnie przybrały postać tzw. paktu fiskalnego. F. Hollande, polityk wszechstronnie wykształcony, a przy tym zdecydowany zwolennik pogłębiania integracji europejskiej, nie ukrywał bowiem, że po zdobyciu władzy będzie szukał innych, niż dotychczasowe, rozwiązań na wyjście strefy euro z kryzysu. W kampanii wyborczej nie wspominał co prawda o emisji euroobligacji, za pomocą których członkowie strefy euro (a głównie niechętne im Niemcy) wspólnie ponosiliby odpowiedzialność za część swych długów, ale zgłaszał inne kontrowersyjne z punktu widzenia dotychczasowej strategii europejskiej propozycje. Opowiadał się za dopisaniem do paktu fiskalnego postulatu dążenia do wzrostu gospodarczego lub stworzenia nowego ,paktu na rzecz wzrostu”, zapowiadającego raczej wydatki publiczne na rzecz rozwoju i walki z bezrobociem, a nie długotrwałe oszczędności. F. Hollande proponował też, aby tzw. złota reguła finansów publicznych, polegająca na wyrugowaniu deficytu budżetowego w przyszłości, była zapisana, ale nie we francuskiej konstytucji tylko w specjalnej ustawie, czyli akcie niższego rzędu. Opowiadał się też za możliwością finansowania działań rządów przez EBC, a jak się wydaje do propozycji emisji euroobligacji, po zwycięstwie wyborczym, także może powrócić. Zwycięstwo wyborcze lidera socjalistów (pamiętać należy, że kanclerz A. Merkel oficjalnie i bezprecedensowo popierała N. Sarkozego) może więc - choć biorąc pod uwagę odpowiedzialność i dojrzałość polityczną Hollande'a wcale nie musi - spowodować chaos polityczny i decyzyjny w UE, stawiając pod wielkim znakiem zapytania sens dotychczas podjętych działań ratunkowych i naprawczych. Z drugiej jednak strony każda kampania wyborcza zawsze rządzi się swoimi prawami, a nowy francuski prezydent ceniony jest za wykształcenie, rozwagę, pragmatyzm i umiejętność kompromisu. Cech tych - jak się wydaje - nie brakuje także niemieckiej kanclerz. Tak więc polityczny duet „Merkollande” skutecznie i wspólnie nadający pożądany ton zmianom w Unii Europejskiej, choć może już nieco innymi metodami, wcale nie jest niemożliwy. 


\title{
The European Union - a dissolution or a reason for macroeconomic and financial balance? Considerations upon the crisis in the euro zone from the European and global perspective
}

\begin{abstract}
Summary
In 2009 the European Union, and in particular the euro zone, slid into a stage of economic recession on account of the spreading global financial crisis, referred to as '2008+.' Considerable developmental problems are being experienced by the group of countries referred to as PIIGS, particularly by Greece, Spain and Italy, which account for nearly $30 \%$ of GDP of the euro zone. Due to the tight developmental interdependencies in the European common market, decreased confidence of global investors, and the consequent potentially lowered profitability of bonds of other Mediterranean economies, the bankruptcy of Greece could cause a domino effect. This could mean serious developmental problems for other indebted Mediterranean economies, such as Italy, Spain and Portugal. It could also drag Germany and France (or their banks, that granted tens of billions of euros in loans to Greece) into financial difficulties, and consequently pose a threat to integration processes throughout Europe. The author of the paper analyzes both the causes and effects of the present financial crisis in the euro zone and presents various scenarios for further developments. He also diagnoses the correctional activities undertaken by selected European governments, the EU and international institutions, their first outcomes, the controversies stirred by the opinions of global rating agencies, and the further developmental prospects for the European Union by 2020.
\end{abstract}

